\title{
Validation of a chromatographic method to routine analysis of trans-resveratrol and quercetin in red wines
}

\author{
Letícia Flores da Silva(1), Celito Crivellaro Guerra(1), \\ Ana Beatriz Costa Czermainski ${ }^{(1)}$, Leonardo Ferrari( ${ }^{(2)}$ and Ana Maria Bergold( ${ }^{(3)}$
}

\begin{abstract}
(1)Embrapa Uva e Vinho, Rua Livramento, no 515, CEP 95700-000 Bento Gonçalves, RS, Brazil. E-mail: leticiaflores.If@outlook.com, celito.guerra@embrapa.br, ana.czermainski@embrapa.br ${ }^{(2)}$ InstitutoFederaldeEducação,CiênciaeTecnologiadoRioGrandedoSul,Campus Bento Gonçalves, Avenida Osvaldo Aranha, no 540, CEP 95700-000 Bento Gonçalves, RS, Brazil. E-mail: leonardo.enologo@gmail.com (3)Universidade Federal do Rio Grande do Sul, Faculdade de Farmácia, Laboratório de Química Farmacêutica, Avenida Ipiranga, № 2.752, CEP 90610-000 Porto Alegre, RS, Brazil. E-mail: ana.bergold@ufrgs.br
\end{abstract}

\begin{abstract}
The objective of this work was to validate a fast method with low-solvent use, for the analysis of trans-resveratrol and quercetin in red wines. The wines were prepared, using a classical method, from the grape (Vitis vinifera) cultivars Cabernet Franc, Cabernet Sauvignon, Malbec, Merlot, Petit Verdot, Pinot Noir, Ruby Cabernet, Syrah, Tannat, and Tempranillo. Samples were filtered and analyzed by high-pressure liquid chromatography (HPLC) with a diode array detector (DAD), at 306 and $371 \mathrm{~nm}$, for trans-resveratrol and quercetin, respectively. An octylsilane column was used, and the mobile phase was composed by a gradient of methanol, water, and formic acid. The method was validated according to the following figures of merit: specificity, linearity, limit of detection, limit of quantification, precision, accuracy, and robustness. The proposed HPLC-DAD method may be established for the analysis of trans-resveratrol and quercetin in red wines.
\end{abstract}

Index terms: Vitis vinifera, high-pressure liquid chromatography, polyphenol, quantification.

\section{Validação de método cromatográfico para análises de rotina de trans-resveratrol e quercetina em vinhos tintos}

\begin{abstract}
Resumo - O objetivo deste trabalho foi validar um método rápido, com baixo consumo de solventes, para a análise de trans-resveratrol e quercetina em vinhos tintos. Os vinhos foram elaborados por método clássico, a partir das cultivares de uva (Vitis vinifera) Cabernet Franc, Cabernet Sauvignon, Malbec, Merlot, Petit Verdot, Pinot Noir, Ruby Cabernet, Syrah, Tannat e Tempranillo. As amostras foram filtradas e analisadas por cromatografia líquida de alta eficiência (CLAE) com detector de arranjo de diodos (DAD), em 306 e 371 $\mathrm{nm}$, quanto ao trans-resveratrol e à quercetina, respectivamente. Utilizou-se uma coluna octilsilano, e a fase móvel foi composta por um gradiente de metanol, água e ácido fórmico. O método foi validado de acordo com as seguintes figuras de mérito: especificidade, linearidade, limite de detecção, limite de quantificação, precisão, exatidão e robustez. O método CLAE-DAD proposto pode ser implantado para análises de transresveratrol e quercetina em vinhos tintos.
\end{abstract}

Termos para indexação: Vitis vinifera, cromatografia líquida de alta eficiência, polifenol, quantificação.

\section{Introduction}

Polyphenols from grapes and wines, such as transresveratrol and quercetin, show a great biological activity and are of interest to medicine, nutrition, and related fields (Ribéreau-Gayon, 2006; Flamini et al., 2013). For this reason, both polyphenols are the most researched ones in viticulture and enology, which involves different wine cultivars, edaphoclimatic factors, production regions or technologies for wine elaboration (Baptista et al., 2001; Malovaná et al., 2001;
Careri et al., 2003; Monagas et al., 2005; Pereira et al., 2010; Aznar et al., 2011; Fontana \& Bottini, 2014).

A great limitation of chemical analysis for the detection and quantification of these compounds is that wines are complex samples, mainly due to the diversity and the high levels of organic compounds (Guerra, 2010; Delcambre \& Saucier, 2013).

Considering these factors, the selective instrumental methods, like the high-performance liquid chromatography (HPLC), are basic to perform qualitative and quantitative analyses of specific 
polyphenols in wines (Baptista et al., 2001; Malovaná et al., 2001; Careri et al., 2003; Monagas et al., 2005; Ribéreau-Gayon, 2006; Pereira et al., 2010; Aznar et al., 2011; Fontana \& Bottini, 2014). Besides this technique, there is a more advanced technology in this equipment line, which is the ultra-performance liquid chromatography (UPLC) that may be associated to a diode array detector (DAD) (Silva et al., 2011) or to mass spectrometry (Ignat et al., 2011; Vrhovsek et al., 2012). However, the UPLC equipment is not available in many laboratories worldwide (Pereira et al., 2010), including those related to enology in Brazil, as this is an expansion field in this country.

The scarcity of publications with specific assays for polyphenols in Brazilian wines indicates that most of the evaluations have been performed by generic and nonselective techniques, such as the determination of total polyphenols in ultraviolet-absorption spectrophotometers (UV) (Ribéreau-Gayon, 2006; Ignat et al., 2011). Hence, the use of HPLC-DAD, which is a more accessible technique than UPLC, and more reliable than UV, would enable the development of strategies to advance the quality of Brazilian products.

One of the drawbacks of HPLC-DAD is that most of the methods for simultaneous analysis of transresveratrol and quercetin are time consuming, taking longer than $30 \mathrm{~min}$ to promote the separation of a variety of compounds with high-chemical similarity (Baptista et al., 2001; Malovaná et al., 2001; Careri et al., 2003; Monagas et al., 2005; Pereira et al., 2010; Fontana \& Bottini, 2014). The possible reason for this high-time taking is the simultaneous analysis of trans-resveratrol, quercetin, and other bioactive polyphenol markers in red wines. In many of these cases, even the sample preparation requires a laborious and costly procedure (Baptista et al., 2001; Malovaná et al., 2001; Monagas et al., 2005; Ignat et al., 2011; Fontana \& Bottini, 2014; Silva et al., 2017b). However, it has been observed that when the goal is the exclusive determination of transresveratrol and quercetin, the time of analysis can be greatly reduced, and the sample manipulation can be simplified, maintaining the results trustable.

Besides the practicality, these optimizations in the technique of analysis allow of the reduction of the mobile phase (MF) volume, the costs, and the generation of chemical residues (Tobiszewski \& Namiésnik, 2012). The HPLC-DAD methods published to date do not simultaneously consider the ideal characteristics of trans-resveratrol and quercetin analysis in Brazilian oenological laboratories, such as: speed of analysis, practicality in the preparation of samples, validation according to Anvisa (2003) requirements, and the application in red wine samples (Baptista et al., 2001; Malovaná et al., 2001; Careri et al., 2003; Monagas et al., 2005; Ribéreau-Gayon, 2006; Pereira et al., 2010; Aznar et al., 2011; Fontana \& Bottini, 2014).

The objective of this work was to validate a fast method with low-solvent use, for the analysis of transresveratrol and quercetin in red wines.

\section{Materials and Methods}

Analytical standards (purity $\geq 90.0 \%$ ) of trans-resveratrol, quercetin, and their possible interferences present in wines (trans-resveratrol-3$b$-D-glucopyranoside, myricetin, kaempferol, and quercetin-3-O-glycoside) were purchased from SigmaAldrich (St. Louis, MO, USA). Stock solutions of each standard $\left(200 \mathrm{mg} \mathrm{L}^{-1}\right)$ were prepared using $50 \% \mathrm{v} / \mathrm{v}$ methyl alcohol $(\mathrm{MeOH})$ as diluent. Cis-resveratrol was obtained by exposing trans-resveratrol $\left(200 \mathrm{mg} \mathrm{L}^{-1}\right)$ to direct sunlight (Baptista et al., 2001; Castellari et al., 2002; Monagas et al., 2005) for 48 hours. The solutions for the method validation were prepared from the stock solution, as described in the following merit figures. As a diluent of these solutions, a synthetic wine was adapted from Malovaná et al. (2001), which was composed of: ethyl alcohol 12\% v/v, $5.5 \mathrm{~g} \mathrm{~L}^{-1} L$-tartaric acid, and $\mathrm{pH} 3.5$ adjusted with $1 \mathrm{~mol} \mathrm{~L}^{-1}$ sodium hydroxide.

Acetonitrile (ACN), $\mathrm{MeOH}$, formic acid (FA), and $L$-tartaric acid were suitable for HPLC (Sigma-Aldrich, St. Louis, MO, USA). Ethyl alcohol, sodium hydroxide, and hydrochloric acid were analytical grade (Merck, Darmstadt, Germany). The solutions were prepared with ultrapure water Milli-Q (Millipore, Billerica, MA, USA). All MF were previously degassed for 10 min, using a T50 ultrasound (Thornton, Porto Alegre, RS, Brazil), a CL vacuum pump (Fanem, São Paulo, SP, Brazil), and manual agitation.

The preparation of each solution for analysis in HPLC-DAD (Shimadzu, Kyoto, Japan) consisted of $2 \mathrm{~mL}$ filtration through a polyvinylidene fluoride (PVDF) membrane with $0.45 \mu \mathrm{m}$ pores (Millipore). The HPLC-DAD system consisted of modules: SPDM10AVP DAD, UFLC CBM-20A control module, two 
LC-10AD pumps, and hand-held injector (Rheodyne, Bensheim, Germany).

Data were obtained and analyzed using the ClassVP application, version 6.12 (Shimadzu, Kyoto, Japan). The methods of Kerem et al. (2004) and Malovaná et al. (2001) were references for the selection of organic MF ( $\mathrm{MeOH}$ or $\mathrm{ACN}$, and $0.1 \% \mathrm{v} / \mathrm{v} \mathrm{FA}$ as additive), column (octylsilane "C8", or octadecylsilane "C18" stationary phases), and organic MF gradient (starting in 0,30 , and $50 \%$, with a maximum of $70 \% \mathrm{v} / \mathrm{v})$. The tested columns were: $\mathrm{C} 8-4.6 \times 150 \mathrm{~mm}, 5 \mu \mathrm{m}$ particles, 100 $\AA$ pores (VertiSep UPS, Vertical, Muang, Nonthaburi, Thailand); $\mathrm{C} 8-4.6 \times 150 \mathrm{~mm}, 5 \mu \mathrm{m}$ particles, $100 \AA$ pores, 5 C8 (ACE, Aberdeen, Craibstone, Scotland); and $\mathrm{C} 18-4.6 \mathrm{x} 150 \mathrm{~mm}, 5 \mu \mathrm{m}$ particles, $120 \AA$ pores (ODS Hypersil, Thermo, Waltham, MA, USA).

The appropriate merit figures for the validation of analytical methods were evaluated according to the following technical descriptions and acceptance limits of Anvisa (2003): specificity, linearity, limits of detection, quantification, precision, accuracy, and robustness. The 'Merlot' samples 1 and 2, from the 2012 harvest in the state of Rio Grande do Sul, were used as a matrix model for validation. SAS/STAT software was applied for data analyses and for the obtention of estimates of these merit figures (SAS Institute Inc., Cary, NC, USA).

Specificity was assessed by analyzing the polyphenols that could interfere with the method, including cis-resveratrol. In addition, the transresveratrol and quercetin standards were subjected to stress condition by acid hydrolysis, in order to obtain possible degradation products (Anvisa, 2003). Solutions were analyzed in triplicate. To this end, the standard solution ( $20 \mathrm{mg} \mathrm{L}^{-1}$ of each) was mixed with an equal volume of $0.1 \% \mathrm{v} / \mathrm{v}$ hydrochloric acid $(\mathrm{pH} 1.8)$ and exposed to $30 \mathrm{~min}$ ultrasound. For each of these specificity assays, the chromatograms were evaluated by DAD (Anvisa, 2003), and the results were compared to an integral standard solution.

An additional specificity assay was performed by analyzing the stability of the analytes against the storage conditions of the 'Merlot' samples (1 and 2), which were stored in microtubes at $-20{ }^{\circ} \mathrm{C}$ for 21 months. Besides, an attempt was made to concentrate the analytes in the sample by heating, adapting the method proposed by Monagas et al. (2005), by using a rotary evaporator at $30{ }^{\circ} \mathrm{C}$. For this, the thermolability was investigated by evaporation of $5 \mathrm{~mL}$ of each sample until dryness in a water bath $\left(50^{\circ} \mathrm{C}\right)$, followed by reconstitution of the residue in $1 \mathrm{~mL}$ of the same diluent used for the analytical standards.

Variance analysis of the obtained area integrations to construct the standard curves in three different days was used to evaluate the linearity of the method. Standard curves were constructed with solutions containing 2.0, 10.0, 15.0, 25.0, and $35.0 \mathrm{mg} \mathrm{L}^{-1}$ of each analyte. The correlation coefficient ( $\mathrm{r}$ ) and the equation of the line for each standard were determined by linear regression using the method of least squares. In addition, the standard curves were determined over two years by control charts, in order to monitor the intercept and slope values corresponding to each analyte. The acceptance limit was the mean $\pm 2 \sigma$ (standard deviation) of the obtained values.

Limits of detection and quantification were estimated from linearity data, such as the mean standard deviation of the intercept of three standard curves and the linear correlation coefficient (Anvisa, 2003).

For the precision and accuracy tests, three levels of trans-resveratrol and quercetin standards were added to the 'Merlot' 2 sample: low $\left(10 \mathrm{mg} \mathrm{L}^{-1}\right)$, medium (15 $\left.\mathrm{mg} \mathrm{L}^{-1}\right)$, and high $\left(25 \mathrm{mg} \mathrm{L}^{-1}\right)$. The precision, expressed in terms of coefficient of variation (CV\%), was calculated based on the quantifications of six injections of these samples fortified with standards in HPLC-DAD. To evaluate the accuracy, the effect of the matrix in each fortified wine was verified by means of recovery calculations (\%) of the added standard.

Robustness was investigated by the evaluation of small variations in the chromatographic conditions most susceptible to changes (Anvisa, 2003). Thus, the MF composition of $0.10 \% \mathrm{v} / \mathrm{v}$ was modified to 0.09 and $0.11 \% \mathrm{v} / \mathrm{v}$ of FA. Another tested modification was in the mark of the reverse phase column $\mathrm{C} 8$ used in the validation, that is, the Vertical column was changed by the ACE one.

After validation, the method was evaluated by the analysis of 12 experimental wine samples, which were elaborated by the classical method (Guerra, 2010) from grapes (Vitis vinifera L.) of red wine grape cultivars Cabernet Franc, Cabernet Sauvignon, Malbec, Merlot, Petit Verdot, Pinot Noir, Ruby Cabernet, Syrah, Tannat, and Tempranillo - of the 2012 harvest, in the state of Rio Grande do Sul, Brazil. Among these samples, two 
were 'Merlot' (1 and 2), two were 'Petit Verdot' (1 and 2 ), and one sample of each of the other cultivars.

Peaks of trans-resveratrol and quercetin were identified in the chromatograms of the samples, by comparing the retention times $\left(\mathrm{R}_{\mathrm{T}}\right)$ and spectra in the ultraviolet (UV) region with the respective standards. Quantification was performed by determining the peak areas of the analytes.

\section{Results and Discussion}

In the development phase of the HPLC-DAD method, a MF composed by $\mathrm{MeOH}$ showed suitable values (FDA, 1994) for resolution ( $>2.0$ ), and peak asymmetry $(\leq 2.0)$, while the use of ACN resulted in asymmetry higher than 2.0. The $\mathrm{C} 8$ phase columns provided a shorter elution time than the $\mathrm{C} 18$ column, without affecting the resolution and the asymmetry. The organic MF starting at $50 \%$ provided the shortest analysis time (10 $\mathrm{min}$ ), in comparison to 0 and $30 \% \mathrm{v} / \mathrm{v}$ (15 min). Therefore, the most suitable chromatographic parameters according to resolution and peak asymmetry, associated to the shortest analysis time, were obtained with the chromatographic conditions for the developed method (Table 1). The proposed HPLCDAD method is fast, with the chromatogram obtained in only ten minutes, while others previously established for analysis of polyphenols take times longer than 30 min (Baptista et al., 2001; Malovaná et al., 2001; Careri et al., 2003; Monagas et al., 2005; Pereira et al., 2010; Fontana \& Bottini, 2014). This time reduction of the analysis was due to the exchange of the traditionally used column $\mathrm{C} 18$ by another with a somewhat more polar (C8) stationary phase, as well as by the use of a gradient with a high proportion of organic MF at the beginning of the method (MeOH $50 \% \mathrm{v} / \mathrm{v})$.
The wavelengths $(\mathrm{nm})$ for the detection of each analyte $\left(10 \mathrm{mg} \mathrm{L}^{-1}\right)$ were set according to the maximum wavelengths $\left(\lambda_{\max }\right)$ obtained for each standard individually, without interferences of the neighboring peaks and the standard diluent (Figure 1 A). Thus, the $\lambda_{\max }$ of 306 and $371 \mathrm{~nm}$ were established for the quantifications of trans-resveratrol and quercetin, respectively.

The $\mathrm{R}_{\mathrm{T}}$ were about 4.1 (trans-resveratrol) and $8 \mathrm{~min}$ (quercetin), which are lower than those reported in the literature (Baptista et al., 2001; Malovaná et al., 2001; Careri et al., 2003; Monagas et al., 2005; Pereira et al., 2010; Aznar et al., 2011; Fontana \& Bottini, 2014; Silva et al., 2017a). Peaks of trans-resveratrol and quercetin of the 'Merlot' 2 sample showed an adequate separation, allowing of the integration of their areas (Figure $1 \mathrm{~B}$ ). The red wines showed several more intense peaks which are probably from other polyphenols at high concentration, such as anthocyanins (Ribéreau-Gayon et al., 2006; Guerra, 2010).

Polyphenols with chemical characteristics similar to trans-resveratrol (cis-resveratrol and trans-resveratrol3- $b$-D-glucopyranoside) and quercetin (myricetin, kaempferol, and quercetin-3-O-glycoside), as well as the degradation products did not interfere with the peaks of interest (Table 2). The elution order of the analytes and interfering compounds was the same as that obtained by other authors (Baptista et al., 2001; Castellari et al., 2002; Wang et al., 2002). The acid hydrolysis products had lower $\mathrm{R}_{\mathrm{T}}$ than the analytes, therefore, they are more polar than their precursors and did not interfere in their analysis (Table 2). The chemical stability of analytes in acid medium was not determined in previous studies (Baptista et al., 2001; Malovaná et al., 2001; Careri et al., 2003; Monagas et al., 2005; Pereira et al., 2010; Fontana \& Bottini, 2014).

Table 1. Analytical conditions adopted for the determination of trans-resveratrol and quercetin in red wines.

\begin{tabular}{|c|c|}
\hline Condition & Description \\
\hline Precolumn & C8 (Phenomenex) \\
\hline Column & C8 VertiSep UPS (Vertical), 4.6 x $150 \mathrm{~mm}, 5 \mathrm{~mm}$ particle and $100 \AA \AA$ pores \\
\hline Mobile phase A & Formic acid $0.10 \% \mathrm{v} / \mathrm{v}$, diluted in ultrapure water \\
\hline Mobile phase B & Formic acid $0.10 \% \mathrm{v} / \mathrm{v}$, diluted in $\mathrm{MeOH}$ \\
\hline Gradient & Linear, with mobile phase A concentrations: $50 \% \mathrm{v} / \mathrm{v}$ from 0 to $5 \mathrm{~min} ; 30 \% \mathrm{v} / \mathrm{v}$ from 7 to $8 \mathrm{~min} ; 50 \% \mathrm{v} / \mathrm{v}$ from 9 to $10 \mathrm{~min}$ \\
\hline Injection volume & $20 \mathrm{~mL}$ \\
\hline Flow rate & $1.0 \mathrm{~mL} \mathrm{~min}^{-1}$ \\
\hline Detection (DAD) & $306 \mathrm{~nm}$ (trans-resveratrol), $371 \mathrm{~nm}$ (quercetin) \\
\hline
\end{tabular}

Pesq. agropec. bras., Brasília, v.51, n.5, p.335-343, maio 2017

DOI: 10.1590/S0100-204X2017000500007 
In the evaluation of the analyte stabilities at $-20^{\circ} \mathrm{C}$, the chromatographic profile was not altered and the analytes were reduced to acceptable levels of $\pm 15 \%$ (Table 3) (Anvisa, 2003). These results indicate that the storage of samples in freezer is adequate within the evaluated period. However, another study investigated the stability of trans-resveratrol in $\mathrm{MeOH}$ solution at $-20^{\circ} \mathrm{C}$, and it determined a maximum time of five days for stock under these conditions (Wang et al., 2002). Ideally, each laboratory should carry out the stability tests, in order to establish the best conditions for storage and preparation of the samples.

The samples showed low values of recovery when subjected to $50^{\circ} \mathrm{C}$ (Table 3). This indicates that this method for concentrating samples through heating is not adequate. In addition, a high $\mathrm{CV} \%$ was found, justified by the excessive handling of the samples
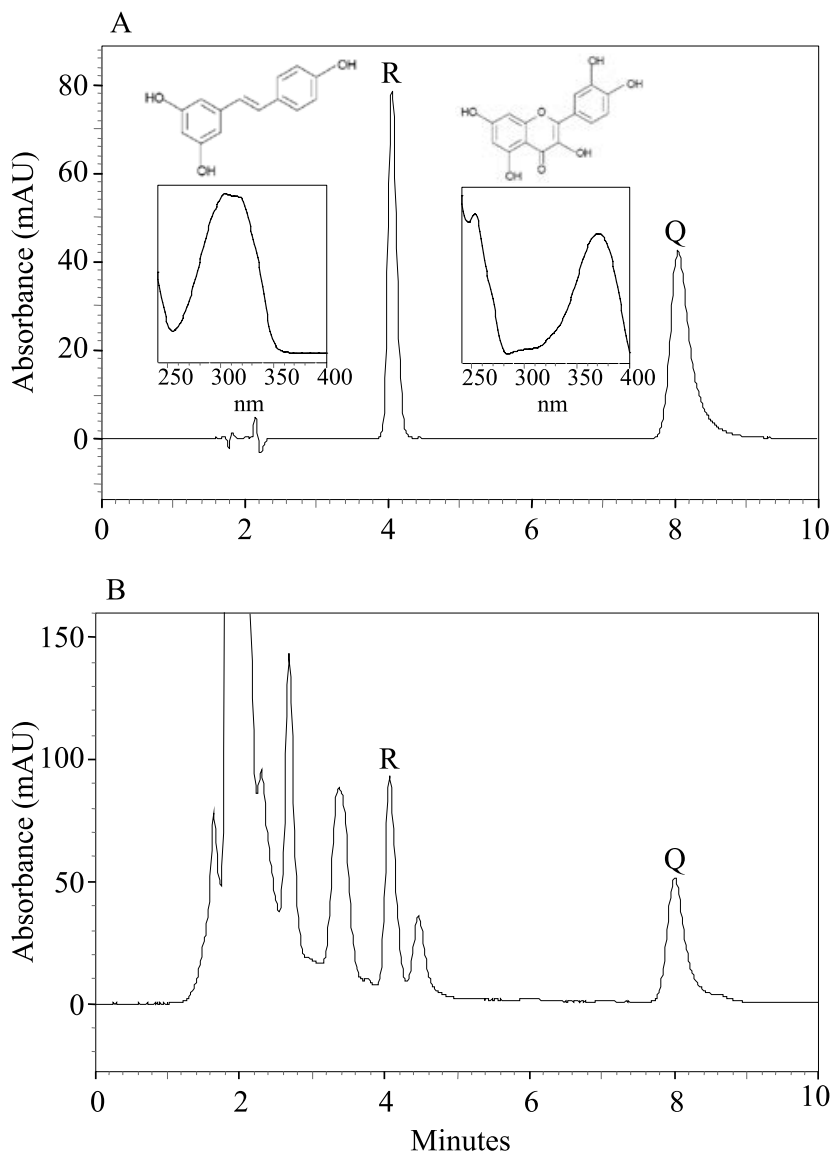

Figure 1. Chromatograms at $340 \mathrm{~nm}$, obtained by HPLCDAD method for: standard solution of trans-resveratrol (R) and quercetin $(\mathrm{Q})$, at $10 \mathrm{mg} \mathrm{L}^{-1}$ concentration, with their respective chemical structures and UV spectra (A), and 'Merlot' 2 red wine (B). mAU, milli-absorbance units. and by the need to reconstitute the obtained residues in the diluent. Monagas et al. (2005) carried out the concentration of polyphenols in wines by a rotary evaporator at $30^{\circ} \mathrm{C}$. Considering that rotary evaporator is not always available in laboratories, and complying with the purpose of providing a simple possible method, this method was disregarded in this study.

The method showed linearity in the range from 2.0 to $35.0 \mathrm{mg} \mathrm{L}^{-1}$ for each analyte, with correlation coefficients above 0.99 (Table 3). The analysis of variance showed the high significance of the linear regression effect $(p<0.01)$, and that there was no significant deviation from linearity $(\mathrm{p}>0.10)$. Regression residual analysis indicated that there was no transgression to the simple linear model. For most of the standard curves used in the control chart ( 1 to 10), the slope and intercept values corresponding to the equation of the line of each analyte were kept within normal limits, mean $\pm 2 \sigma$ (Figure 2). Only one point was out of limits, which can be observed in the transresveratrol intercept (curve 4, Figure 2 A). For this reason, laboratories can use tools like control charts to follow the standard curves, especially in exchange cases of equipment, analysts, and chemicals. In this way, it is possible to identify possible laboratory errors related to the standard curve. The control chart data can be used as research aid, in case of results from areas outside the specification, as indicated by the FDA (2006) and Kuselman et al. (2012).

The limits of detection and quantification were determined and were lower than the levels usually found ( 0 to $6.5 \mathrm{mg} \mathrm{L}^{-1}$ for trans-resveratrol, and 0 to $8.84 \mathrm{mg} \mathrm{L}^{-1}$ for quercetin), mainly for red wines (Baptista et al., 2001; Malovaná et al., 2001; Careri et al., 2003; Monagas et al., 2005; Guerra et al., 2008;

Table 2. Evaluation of possible interferers in the HPLCDAD method for the analysis of trans-resveratrol and quercetin in red wines.

\begin{tabular}{lcc}
\hline Possible interferer & $\begin{array}{c}\mathrm{R}_{\mathrm{T}} \\
(\mathrm{min})\end{array}$ & $\begin{array}{c}\lambda_{\max } \\
(\mathrm{nm})\end{array}$ \\
\hline Stilbenes & & \\
$\quad$ Trans-resveratrol-3- $\beta$-D-Glucopyranoside & 2.6 & 306 \\
$\quad$ Cis-resveratrol & 8.6 & 285 \\
\hline Flavonols & & \\
$\quad$ Myricetin & 4.5 & 374 \\
$\quad$ Kaempferol & 9.3 & 365 \\
Quercetin-3-O-glucoside & 3.5 & 354 \\
\hline Acid hydrolysis - trans-resveratrol & 3.6 & 306 \\
\hline Acid hydrolysis - quercetin & 7.4 & 371 \\
\hline
\end{tabular}


Pereira et al., 2010; Silva et al., 2011; Vrhovsek et al., 2012; Fontana \& Bottini, 2014).

According to $\mathrm{CV} \%$ values (less than $15 \%$ ), the method was considered accurate (Table 3). Accuracy was shown by recoveries between 85 and $115 \%$, indicating that the matrix does not interfere with the developed methodology.

The method was also robust as for the changes in the concentration of FA in the MF and in the column mark, since the peaks did not change significantly $(\mathrm{CV}<5.0 \%)$ for their $\mathrm{R}_{\mathrm{T}}$ and areas (Table 3). The $\mathrm{pH}$ of the original MF $(0.1 \% \mathrm{v} / \mathrm{v} F A)$ was 3.19 , and underwent a slight variation in the concentrations of $0.09 \% \mathrm{v} / \mathrm{v}$ $(\mathrm{pH}=3.30)$ and $0.11 \% \mathrm{v} / \mathrm{v}(3.10)$.

The results obtained for the merit figures evaluated for this HPLC-DAD method were in agreement with the acceptable limits (Anvisa, 2003). Most of the previous studies did not show or perform a partial validation (Malovaná et al., 2001; Castellari et al., 2002; Kerem et al., 2004; Monagas et al., 2005; Pereira et al., 2010; Aznar et al., 2011). Baptista et al. (2001), Careri et al. (2003), and Silva et al. (2017a) validated a method by HPLC-DAD; however, these authors applied it for 60 , 35, and 30 min, respectively. Fontana \& Bottini (2014) and Silva et al. (2017b) validated a method by HPLCDAD which requires a complex sample preparation. Silva et al. (2011), Silva et al. (2017b), and Vrhovsek et al. (2012) validated methods for assaying various polyphenols in wines using the UPLC equipment.

For each analyte peak of most red wines, a purity greater than $95 \%$ was found, which reduces the possibility of coelution with other compounds. An exception was observed for wines of the cultivars Syrah, Tempranillo, and Petit Verdot, with a peak purity of 90-95\% for trans-resveratrol. Therefore, if purity peaks less than $90 \%$ are observed, it is advisable to use a longer run-time method to promote a better separation between the analyte and interferers (Kazakevich \& Lobrutto, 2007). It is possible, then, to ensure compliance with the selectivity requirements recommended by regulatory agencies (Anvisa, 2003). The twelve red wines showed variations for the contents of the polyphenolic compounds (Figure 2). The values varied according to the expected ones for the analyzed cultivars (Guerra et al., 2008). For wines, the levels of trans-resveratrol varied from 2.46 to $15.88 \mathrm{mg} \mathrm{L}^{-1}$, and those of quercetin from 3.85 to $26.51 \mathrm{mg} \mathrm{L}^{-1}$ (Figure 3). These results were similar or superior to those obtained in previous studies on red wines from several regions worldwide (Baptista et al., 2001; Careri et al., 2003; Monagas et al., 2005; Pereira et al., 2010; Silva et al., 2011; Vrhovsek et al., 2012; Fontana \& Bottini, 2014). A higher concentration of quercetin ( $38.55 \mathrm{mg} \mathrm{L}^{-1}$ ) was found in samples of wines from the Canary Islands (Malovaná et al., 2001). The samples of 'Pinot Noir' and 'Merlot' 2 showed high values of the two

Table 3. Merit figures of the chromatographic method (HPLC-DAD) for analysis of trans-resveratrol and quercetin in red wines.

\begin{tabular}{|c|c|c|c|}
\hline Merit figure & Limit & Trans-resveratrol & Quercetin \\
\hline \multicolumn{4}{|l|}{ Specificity (Merlot 2) } \\
\hline Stability ${ }^{(1)}\left(-20^{\circ} \mathrm{C}\right)$ & $85-115(<5)^{(5)}$ & $103.06(4.94)$ & $89.34(1.81)$ \\
\hline Stability ${ }^{(1)}\left(50^{\circ} \mathrm{C}\right)$ & $85-115(<5)^{(5)}$ & $81.58(10.83)$ & $89.69(16.08)$ \\
\hline \multicolumn{4}{|l|}{ Linearity } \\
\hline Equation of the line ${ }^{(2)}$ & - & $\mathrm{y}=123,723.0 x+8,015.0$ & $y=109,813.0 x-124,862.0$ \\
\hline$r^{(2)}$ & $0.99^{(5)}$ & 0.9947 & 0.9951 \\
\hline Linear regression $^{(3)}$ & $>9.33$ & 1012.85 & 1474.19 \\
\hline Linearity deviation ${ }^{(3)}$ & $<5.41$ & 0.29 & 1.50 \\
\hline Linear range $\left(\mathrm{mg} \mathrm{L}^{-1}\right)$ & - & 2.0 to 35.0 & 2.0 to 35.0 \\
\hline \multicolumn{4}{|l|}{ Limits } \\
\hline Detection $\left(\mathrm{mg} \mathrm{L}^{-1}\right)$ & - & 0.22 & 0.33 \\
\hline Quantification (mg L-1) & - & 0.68 & 0.99 \\
\hline Precision $\left(\mathrm{CV}_{1} \%\right)$ & $<5.00^{(5)}$ & 7.84 & 2.52 \\
\hline Accuracy $^{(1,4)}(\%)$ & $85-115^{(5)}$ & $99.74(4.37)$ & $106.90(2.22)$ \\
\hline \multicolumn{4}{|l|}{ Robustness } \\
\hline $\mathrm{MF}-\% \mathrm{FA}\left(\mathrm{CV}_{2} \%\right)$ & - & 4.78 & 6.31 \\
\hline Column marck $\left(\mathrm{CV}_{3} \%\right)$ & - & 3.97 & 4.63 \\
\hline
\end{tabular}

${ }^{(1)}$ Average $(\%)$ and $\mathrm{CV} \%$ calculated for recovery $(\mathrm{n}=3) \cdot{ }^{(2)}$ Calculated from standard solutions analyzed over the same sample period (curves 1,2 , and 3 of Figure 3). ${ }^{(3)}$ Analysis of variance $(\mathrm{p}=0.01) .{ }^{(4)}$ Calculated for 'Merlot' 2 wine at low $\left(10 \mathrm{mg} \mathrm{L}^{-1}\right)$, medium $\left(15 \mathrm{mg} \mathrm{L}^{-1}\right)$ and high $\left(25 \mathrm{mg} \mathrm{L}^{-1}\right)$ concentration levels. ${ }^{(5)}$ Anvisa (2003) and FDA (2001). 

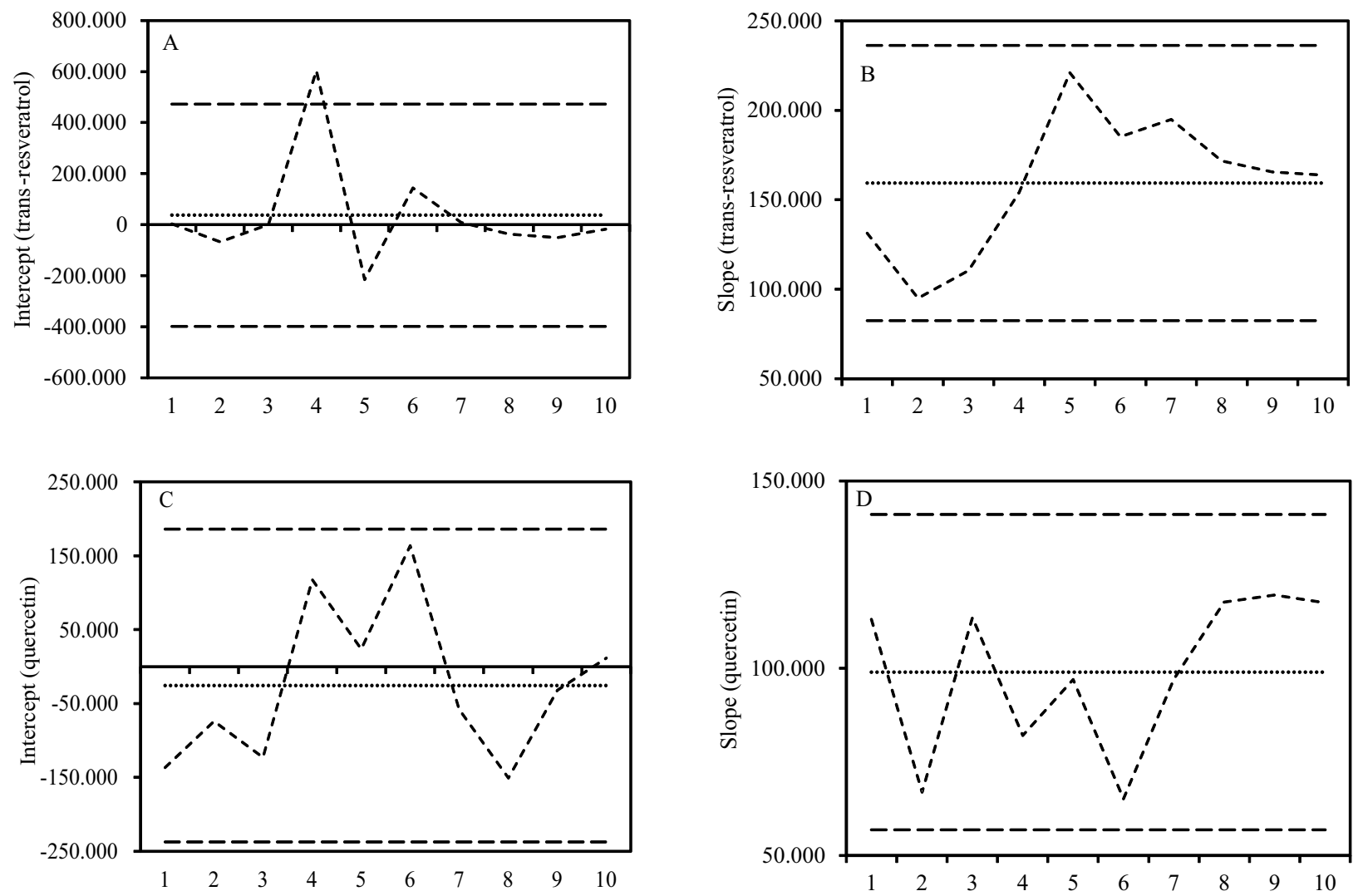

-.-.- Value - - - - Inferior limit _ - - - Superior limit ………... Mean

Figure 2. Control charts for ten standard curves for each analyte: A, trans-resveratrol intercept; B, trans-resveratrol slope; C, quercetin intercept; $\mathrm{D}$, quercetin slope. Circle indicates value outside the specification (mean $\pm 2 \sigma$ ), which was disregarded.

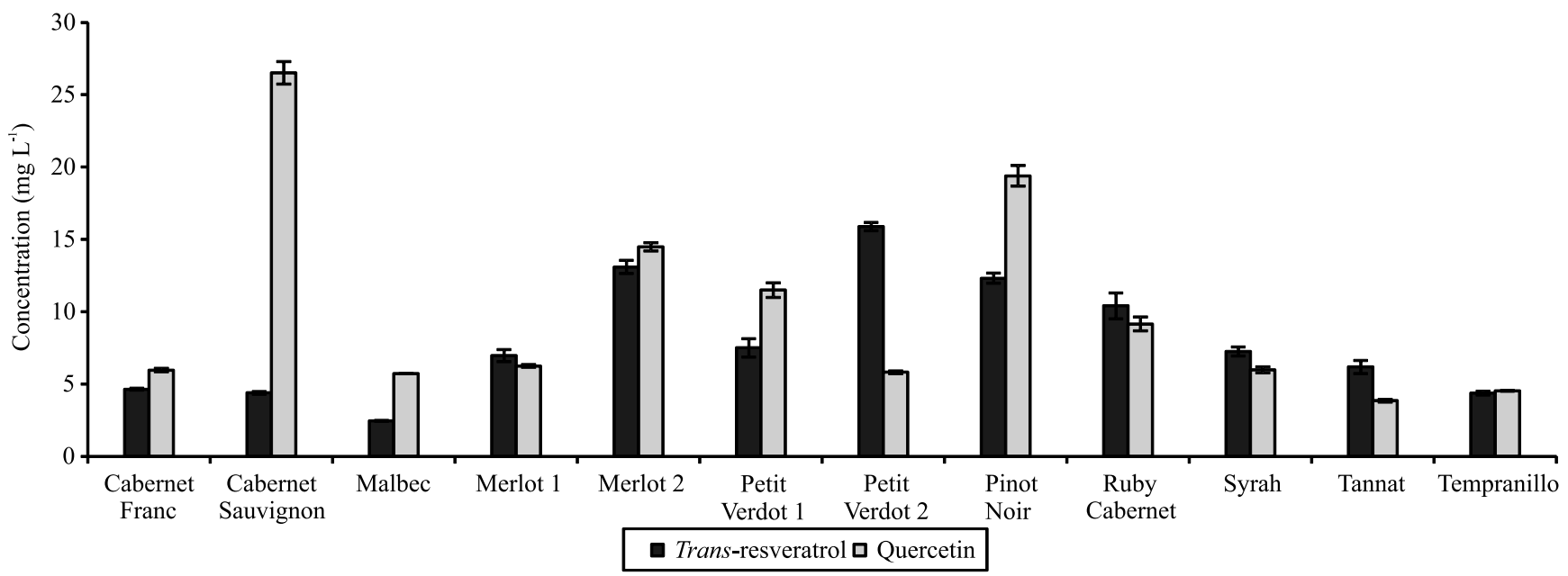

Figure 3. Mean and standard veviation of trans-resveratrol and quercetin contents for samples of red wines made with grapes from the 2012 harvest in the state of Rio Grande do Sul. 
analytes, in contrast to 'Malbec' (Figure 3). Analyses of a greater number of samples of these cultivars are required to verify if these contents are typical of the region under study.

\section{Conclusions}

1. The method developed by HPLC-DAD is suitable for the analysis of trans-resveratrol and quercetin in red wines.

2. This HPLC-DAD method is faster and generates less volume of chemical residues than those available in the scientific literature.

\section{Acknowledgments}

To our colleagues Magda Beatris Gatto Salvador and Celso Guarani Ruiz de Oliveira, for their support in the management of Lacem-Embrapa; to Gisele Eliane Perissutti, from the Laboratório de Enoquímica Laeno-Embrapa, for the classical analyses; and to Raul Luiz Ben and to Anevir Marin, for the experimental vinifications.

\section{References}

ANVISA. Agência Nacional de Vigilância Sanitária. Resolução$\mathrm{RE} \mathrm{n}^{\circ} 899$, de 29 de maio de 2003. [Guia para validação de métodos analíticos e bioanalíticos]. Diário Oficial da União, 2 jun. 2003. Seção 1, p.56-59.

AZNAR, O.; CHECA， A.; OLIVER， R.; HERNÁNDEZCASSOU, S.; SAURINA, J. Determination of polyphenols in wines by liquid chromatography with UV spectrophotometric detection. Journal of Separation Science, v.34, p.527-535, 2011. DOI: $10.1002 /$ jssc.201000816.

BAPTISTA, J.A.B.; TAVARES, J.F. da P.; CARVALHO, R.C.B. Comparison of polyphenols and aroma in red wines from Portuguese mainland versus Azores Islands. Food Research International, v.34, p.345-355, 2001. DOI: 10.1016/S09639969(00)00174-5.

CARERI, M.; CORRADINI, C.; ELVIRI, L.; NICOLETTI, I.; ZAGNONI, I. Direct HPLC analysis of quercetin and transresveratrol in red wine, grape, and winemaking byproducts. Journal of Agricultural and Food Chemistry, v.51, p.52265231, 2003. DOI: 10.1021/jf034149g.

CASTELLARI, M.; SARTINI, E.; FABIANI, A.; ARFELLI, G.; AMATI, A. Analysis of wine phenolics by high-performance liquid chromatography using a monolithic type column. Journal of Chromatography A, v.973, p.221-227, 2002. DOI: 10.1016/ S0021-9673(02)01195-0.
DELCAMBRE, A.; SAUCIER, C. High-throughput oenomics: shotgun polyphenomics of wines. Analytical Chemistry, v.85, p.9736-9741, 2013. DOI: $10.1021 / \mathrm{ac} 4021402$.

FDA. Food and Drug Administration. Guidance for industry: bioanalytical method validation. 2001. Available at: $\quad<$ http://www.fda.gov/downloads/Drugs/Guidance ComplianceRegulatoryInformation/Guidances/ucm070107.pdf $>$. Accessed on: Jan. 52016.

FDA. Food and Drug Administration. Guidance for industry: investigating out-of-specification (OOS) test results for pharmaceutical production. 2006. Available at: $<$ http://www.fda. gov/downloads/Drugs/.../Guidances/ucm070287.pdf>. Accessed on: Sept. 242015.

FDA. Food and Drug Administration. Reviewer guidance: validation of chromatographic methods. 1994. Available at: $<$ http://www.fda.gov/downloads/Drugs/Guidances/ UCM134409. pdf $>$. Accessed on: Sept. 92016.

FLAMINI, R.; MATTIVI, F.; DE ROSSO, M.; ARAPITSAS, P.; BAVARESCO, L. Advanced knowledge of three important classes of grape phenolics: anthocyanins, stilbenes and flavonols. International Journal of Molecular Sciences, v.14, p.1965119669, 2013. DOI: 10.3390/ijms141019651.

FONTANA, A.R.; BOTTINI, R. High-throughput method based on quick, easy, cheap, effective, rugged and safe followed by liquid chromatography-multi-wavelength detection for the quantification of multiclass polyphenols in wines. Journal of Chromatography A, v.1342, p.44-53, 2014. DOI: 10.1016/j.chroma.2014.03.044.

GUERRA, C.C. Vinho tinto. In: VENTURINI FILHO, W.G. (Coord.). Bebidas alcoólicas: ciência e tecnologia. São Paulo: Blucher, 2010. v.1, p.209-233. (Série Bebidas).

GUERRA, C.C.; ZUCOlOtTO, M.; TONIETTO, J. Profil chimique et sensoriel de vins rouges brésiliens selon le cépage et l'origine géographique des vignobles. In: CONGRÈS INTERNATIONAL DES TERROIRS VITICOLES, 7., 2008, Nyon, Suisse. Comptes rendus. Pully: Agroscope Changins Wädenswill, 2008. p.493-499.

IGNAT, I.; VOLF, I.; POPA, V.I. A critical review of methods for characterisation of polyphenolic compounds in fruits and vegetables. Food Chemistry, v.126, p.1821-1835, 2011. DOI: 10.1016/j.foodchem.2010.12.026

KAZAKEVICH, Y.; LOBRUTTO, R. (Ed.). HPLC for pharmaceutical scientists. New Jersey: J. Wiley \& Sons, 2007. 1140p. DOI: $10.1002 / 0470087951$

KEREM, Z.; BRAVDO, B.; SHOSEYOV, O.; TUGENDHAFT, Y. Rapid liquid chromatography-ultraviolet determination of organic acids and phenolic compounds in red wine and must. Journal of Chromatography A, v.1052, p.211-215, 2004. DOI: 10.1016/j. chroma.2004.08.105.

KUSELMAN, I.; PENNECCHI, F.; BURNS, C.; FAJGELJ, A.; ZORZI, P. IUPAC/CITAC Guide: investigating out-ofspecification test results of chemical composition based on metrological concepts (IUPAC Technical Report). Pure Applied Chemistry, v.84, p.1939-1971, 2012. DOI: 10.1351/PACREP-11-10-04. 
MALOVANÁ, S.; MONTELONGO, F.J.G.; PÉREZ, J.P.; RODRÍGUEZ-DELGADO, M.A. Optimisation of sample preparation for the determination of trans-resveratrol and other polyphenolic compounds in wines by high performance liquid chromatography. Analytica Chimica Acta, v.428, p.245-253, 2001. DOI: 10.1016/S0003-2670(00)01231-9.

MONAGAS, M.; SUÁREZ, R.; GÓMEZ-CORDOVÉS, C.; BARTOLOMÉ, B. Simultaneous determination of nonanthocyanin phenolic compounds in red wines by HPLCDAD/ESI-MS. American Journal of Enology and Viticulture, v.56, p.139-147, 2005.

PEREIRA, V.; CÂMARA, J.S.; CACHO, J.; MARQUES, J.C. HPLC-DAD methodology for the quantification of organic acids, furans and polyphenols by direct injection of wine samples. Journal of Separation Science, v.33, p.1204-1215, 2010. DOI: 10.1002/jssc. 200900784 .

RIBÉREAU-GAYON, P.; GLORIES, Y.; MAUJEAN, A.; DUBOURDIEU. D. Handbook of enology: the chemistry of wine stabilization and treatments. $2^{\text {nd }}$ ed. Chichester: J. Wiley \& Sons, 2006. v.2, 441p. DOI: 10.1002/0470010398.fmatter.

SILVA, C.L.; PEREIRA, J.; WOUTER, V.G.; GIRÓ, C.; CÂMARA, J.S. A fast method using a new hydrophilic-lipophilic balanced sorbent in combination with ultra-high performance liquid chromatography for quantification of significant bioactive metabolites in wines. Talanta, v.86, p.82-90, 2011. DOI: 10.1016/j. talanta.2011.08.007.
SILVA, L.F. da; GUERRA, C.C.; FORESTI, A.; BERGOLD, A.M. Verification of the selectivity of a liquid chromatography method for determination of stilbenes and flavonols in red wines by mass spectrometry. Chemical Papers, v.71, p.661-672, 2017a. DOI: $10.1007 / \mathrm{s} 11696-016-0066-7$.

SILVA, L.F. da; GUERRA, C.C; KLEIN, D.; BERGOLD, A.M. Solid cation exchange phase to remove interfering anthocyanins in the analysis of other bioactive phenols in red wine. Food Chemistry, v.227, p.158-165, 2017b. DOI: 10.1016/j. foodchem.2017.01.087.

TOBISZEWSKI, M.; NAMIÉSNIK, J. Direct chromatographic methods in the context of green analytical chemistry. Trends in Analytical Chemistry, v.35, p.67-73, 2012. DOI: 10.1016/j. trac.2012.02.006.

VRHOVSEK, U.; MASUERO, D.; GASPEROTTI, M.; FRANCESCHI, P.; CAPUTI, L.; VIOLA, R.; MATTIVI, F. A versatile targeted metabolomics method for the rapid quantification of multiple classes of phenolics in fruits and beverages. Journal of Agricultural and Food Chemistry, v.60, p.8831-8840, 2012. DOI: $10.1021 /$ jf2051569.

WANG, Y.; CATANA, F.; YANG, Y.; RODERICK, R.; BREEMEN, R.B. van. An LC-MS method for analyzing total resveratrol in grape juice, cranberry juice, and in wine. Journal of Agricultural and Food Chemistry, v.50, p.431-435, 2002. DOI: $10.1021 /$ jf010812u.

Received on January 22, 2016 and accepted on September 23, 2016 